\title{
Dynamics of Land Use/Cover Trends in Kanungu District, South-western
} Uganda

\section{BARASA BERNARD*1; ${ }^{1}$ EGERU ANTHONY ${ }^{1}$; OKELLO PATRICK $^{2}$; MUTUZO FRIDAH ${ }^{3}$}

\author{
${ }^{1}$ Institute of Environment and Natural Resources, Makerere University \\ P. O. Box 7062, Kampala Uganda. ${ }^{2}$ Uganda Bureau of Statistics, P.O. Box \\ 7186, Kampala \\ ${ }^{3}$ Ministry of Lands, Housing and Urban Development P.O. BOX 7069, Kampala
}

\begin{abstract}
Like other countries in the Sub-Saharan Africa, Uganda is not an exception to the effects of land use/cover changes on the environment. Specifically the study intended to; determine the magnitude and trend of land use/cover changes in Kanungu District for the last 35 years. A series of Landsat TM/ETM orthorectified satellite imagery of 1975, 1987 and 1999 were classified using unsupervised classification procedures in ILWIS 3.3 software to determine the magnitude and trend of land use/cover changes. A total of 65 local residents were randomly selected for questionnaire administration with the help of village leaders to examine the underlying drivers of land use/cover change. The results showed that the magnitude of small scale (Non-uniform) farming largely increased by 5\% from 1975 to 1999 while areas covered by Tropical high forest relatively decreased by $16 \%$ between 1975 and 1987 but slightly increased by $1 \%$ in 1999 . The areas covered by wetlands comparatively increased by $4 \%$ from 1975 to 1987 and by 1999 they slightly decreased by 3\%. The woodland areas decreased by 3\% from 1975 to 1987 and to some extent also increased by $2 \%$ in 1999 . Household size, type of crops grown, customary land tenure system, availability of agricultural extension workers, weak environmental laws and policies are significant predictors of land use/cover change in Kanungu District.@ JASEM
\end{abstract}


Landuse/cover change affects environmental and social economic conditions (Krishna et al., 2003; Mundia \& Aniya, 2006). The drivers of land use/cover change vary in nature and magnitude from one region to another. For instance, in the tropics, land-use/cover change is largely driven by extensive agricultural practices, high population growth rates, infrastructural developments and weak environmental laws and policies (Geist \& Lambin, 2002; Makalle et al., 2008). The exponential population growth and shifting cultivation are causally linked to deforestation and environmental degradation (Jarosz, 1993). However, most of Africa and Latin America have increased their food production through both agricultural intensification and extensification (Lambin et al., 2003).

In Uganda, the combined effect of high economic growth and population growth has had and will continue to have dramatic impacts on the natural land cover (NBS, 2003). The decline in natural land cover in Kanungu District is majorly attributed to intensive agricultural activities primarily triggered by high population growth rates of about $3 \%$ per year (UBOS, 2002). Unfortunately, the underlying drivers of land use/cover change, their magnitude and trend in Kanungu District have not been documented. Therefore the study seeks to inform all the stakeholders about the need to promote sustainable development and protect the diverse natural resources in the District.

\section{MATERIALS AND METHODS}

The study was carried out in Kanungu District which is located in south western Uganda bordering the Districts of Rukungiri in the north and east, Kabale in south east, Kisoro in the south and Democratic Republic of Congo in the west. The district has a total population of 204,732. The District comprises of fairly flat topped hills with gentle sloping sides and broad valleys. The hills gradually increase in height to the highlands of Rutenga with Burimbi peak of Mafuga being the highest at $822222 \mathrm{ft}(2503 \mathrm{~m})$ above sea level (SOER, 2004).

The study utilized ortho-rectified and cloud free Landsat TM/ETM images of 1975, 1987 and 1999 (30m spatial resolution) to determine the magnitude and trends of land use/cover changes. The orthorectified satellite images were subjected to unsupervised classification procedures using ILWIS 3.3 software. The unsupervised classification was used because of more information present in unsupervised than in supervised classification (Jensen, 1986). The images were assigned to four land use/cover types with descriptions according to Uganda National Biomass Study Classification
System (2003). The preliminary maps were validated and adjusted basing on ground truthed data and the topographic sheet of $1965(1: 50,000)$ for Kanungu District. The time series regressions were used to determine the trend of all the land use/cover types. The change rates of single land use/cover type were determined according to Peng et al., (2008) procedures. The study also administered 65 structured questionnaires to the randomly selected local residents and villages with the help of local council leaders to give an insight into the main driving forces of land use/cover change. Six key informants (District agricultural and commercial production officers, NAADS coordinator and Environmental Officers) were also purposively selected for interviewing. In addition, four focus group discussions were conducted in each sampled village. The issues addressed included population trends, environmental issues, policies, sources of livelihood and type of crops grown. The socio-economic data was analysed using SPSS Windows Programme (10.0) and subjected to Logistic Regression. The logistic model was used because land use/cover is normally expressed as a discrete variable (Jan et al, 2005).

\section{RESULTS AND DISCUSSION}

For the last 35 years, small scale (Non-uniform) farming enormously increased from $60 \%$ in 1975 to $75 \%$ in both 1987 and 1999 while areas covered by Tropical High Forest and woodlands decreased from $32 \%, 7 \%$ in 1975 to $16 \%, 4 \%$ in 1987 but gradually increased to $17 \%$ and $6 \%$ in 1999 respectively. However, areas covered by wetlands comparatively gained more land in 1987 (5\%) compared to 1999 (2\%) and 1975 (1\%). In period of 1975 and 1987, the highest annual land use change rate was experienced in wetlands $(44 \%)$ compared to tropical high forest (5\%), woodlands (5\%) and small scale (Non-uniform) farming (2\%) while between 1987 and 1999 the highest annual land use change rate was experienced in woodlands $(7 \%)$ followed by wetlands $(6 \%)$, tropical high forest (1\%) and small scale (nonuniform) farmlands $(0.1 \%)$. The time series regressions showed that small scale (Non-uniform) farming (0.829) and Tropical High Forest (0.697) had relatively strong regression strength and good fit compared to wetlands (0.053) and woodlands (0.049) with very weak regression strength and a weak fit. The forecasts show that small scale (Non-uniform) farming and wetlands are likely to gain more land in 2011 (6773 ha), (305 ha) and in 2023 (7376 ha), (346 ha) respectively while in 2011 the areas covered with tropical high forest and woodlands will reduce from 490 ha, 391 ha to 112 ha and 354 ha in 2023 correspondingly if the nature of developments stayed the same in the District. 
According to the logistic model, the log of households clearing natural land cover for agricultural activities was negatively related to the low education levels (odds ratio of .750) and customary land tenure (odds ratio of .951$)(P<0.05)$ whereas positively related to the household size (odds ratio of 3011.048), weak environmental laws and policies (odds ratio of 431.071), type of crops grown (odds ratio of 1.212), availability of agricultural extension workers (odds ratio of 2.102) $(P<0.05)$. In other words, household size, weak environment laws and policies, type of crops grown, availability of agricultural extension workers, and customary land tenure were statistically significant predictors of land use/cover change $(P<0.05)$ compared to the increasing livestock activities and low education levels which were non significant drivers of land use/cove change in the District $(P<0.05)$. The Hosmer-Lemeshow $(\mathrm{H}-\mathrm{L})$ test yielded a $\mathrm{X}^{2}(8)$ of 53.322 and was significant $(P<.05)$. The overall correction prediction is 76.7 , an improvement over the chance level.

Generally, the rates of change in land use/cover units have not been uniform across board. The variations are distinct; increases in small-scale farming carried out by resource-poor farmers are held accountable for decreases in areas covered by wetlands, tropical high forests and woodlands. This is also similar to the findings made by Egeru and Majaliwa, 2009 in Soroti District. The encroachment onto natural forests and wetlands explains the magnitude of change experienced in these land cover units between 1987 and 1999. The rapid changes experienced in the wetlands between 1975 and 1987, are intricately difficult to point to a signal factor to explain this land use/cover trend. However, residents in the District attributed this to increase in population and the realization that there was a shortage of land. This made the communities to encroach on the wetlands for cultivatable land and to establish agro-forestry gardens of eucalyptus. In addition, the break down in civil laws at this time as the communities were emerging out of conflict that had plunged the country in the 1980s further explains the declines in wetland cover.

There was much clearance of forest cover to make settlements in Bwindi Impenetrable Forest Reserve during the troubled 1970s and 1980s. Residual encroachment of the government lands still continues in the District. Most of the boundaries of the encroached reserve have not been reopened and are not clearly demarcated, which forms part of the reason for the current confusion in the District (SOER, 2007). The R-square values posted from the regressions vary distinctively; Small-scale farmlands (0.723), tropical high forest (0.697), wetlands (0.049), and woodlands $(0.053)$. This scenario reflects two strands; the first explains the relatively high R-square values for small-scale farmlands and Tropical High Forests. In these two units, the rates of change are still very high; land is more sought from the tropical high forest by small-scale farmers that are expanding their cultivable land. On the other hand, the lower RSquare values from wetlands and woodlands is a situation of exhaustion of these type of land cover units thus the rates of change are no longer drastic because there is very little to clear. In essence therefore, there is a lower rate of change occurring within the woodlands and wetlands compared to the Tropical High Forest.

The study findings also revealed that household size, weak environment laws and policies, type of crops grown, availability of agricultural extension workers and customary land tenure system are vital underlying drivers of land use/cover change in Kanungu District. On contrary, the increasing livestock activities and low education levels turned out to be non important underlying drivers of land use/cover change. The higher the household size the more likely a household was to drive change in land use/cover-population destabilization notion. This argument is reinforced by the assertion made by Ramankutty et al., (2002) that the driving force for most land use change is population growth. The mean household size of Kanungu District was 4.7 persons (Census Atlas, 2002). Equally social ties of extended families in the area have kept the household sizes larger and this has a bearing on land use patterns especially cultivation of gardens so as to meet the household food requirements. Deforestation in turn reduces tree species diversity and erodes the genetic base of tropical trees, including those vital for the very survival of the population. This scenario seems apparent in the District.

Mwavu (2008) also noted that the weak environmental laws and policies are responsible for the clearances of natural land cover because they are highly violated and usually have lighter penalties. This is also inline with results made by Kamusoko (2007), in a study conducted in Zimbabwe that rapid land use/cover change is a result of colonial imbalances in land distribution, government policies and environmental factors such as drought. The customary land tenure system in the District is as well an underlying driver of land use/cover change; the tradition of inheritance and parcel sub-division to sons who have either reached marital age or have already married and started their own families has encouraged further sub-division of land. Land fragmentation in the area has therefore been unavoidable circumstance. There are particularly two issues that this has raised in the area; establishment of new homesteads in itself requires land clearance, there is a cultural erosion of environmental 
custodianship as the elders relinquish their powers to the newly created households. Place and Ostuka, (1997) had earlier on also argued that land use and land cover change is closely linked to customary land tenure institutions. The type of crops grown in the District such as tobacco, bananas, matooke, beans, maize have also led to the massive clearances of areas covered by tropical high forest and wetlands to increase yields for both sale and home consumption. The availability of agricultural extension workers have greatly contributed to the increase in household income levels through better farm yields and thus raising the standards of living in the District. However, this has led to the clearance of natural land cover using the acquired income to pay for labour used in agricultural activities such as land clearing and digging.

Acknowledgment: We thank the entire research team for time rendered while carrying out the household survey and MUIENR for the provision of secondary data and field funds.

\section{REFERENCES}

Census Atlas (2002). Uganda population and housing census. Mapping socio-economic indicators for national development.

Egeru, A; Majaliwa, M.G.J (2009). Land use/cover trend in Soroti District Eastern Uganda. Journal of Applied Sciences and Management Vol. 13(4) 77 - 79.

FAO (2006). Livestock's long shadow; 00153 Rome, Italy

Geist, H; Lambin, E (2002). Proximate causes and underlying driving forces of tropical deforestation. Bioscience 52, 143-50.

Jan P. L; Peter H. V; Steven, J (2005). Statistical methods for analyzing the spatial dimension of changes in land use and farming systems. LUCC Report Series 7. Published by: International Livestock Research Institute. ISBN: 92-9146-178-4, ISSN 1138-7424

Jarosz, L (1993). Defining and Explaining Tropical Deforestation: Shifting Cultivation and Population Growth in Colonial Madagascar (1896-1940), Economic Geography, Vol. (69), No. 4, Environment and Development, Part, pp. 366-379. Published by Clark University.

Jensen, J (1986). Introductory digital image processing - A remote sensing perspective. Prentice Hall, New York, USA.
Kamusoko, C; Aniya, M (2007). Land use/cover Change and Landscape Fragmentation Analysis in the Bindura District, Zimbabwe. Land Degradation and Development (18), 221-233

Krishna, P; Stinner, B; Deb, S; Cardina, J; Moore, R; Prabhat, K; Harao, T; Kiyoto, T; Badarinath, K; Casey, H (2003). Trends in food production and nitrous oxide emissions from the agriculture sector in India: environmental implications. Regional Environmental Change. Vol.(3). no.4. pp. 154-161. DOI: 10.1007/s10113-002-0055-y.

Lambin, E; Helmut, J; Erika, L (2003). Dynamics of LandUse and Land-Cover Change in Tropical Regions. Annu. Rev. Environ. Resource. Vol. (28) 205-401.

Makalle, A; Obando, J; Bamutaze, Y (2008). Effects of land use practices on livelihoods in the trans-boundary sub-catchments of the Lake Victoria Basin. African Journal of Environmental Science and Technology Vol. 2 (10). pp. 309-317. ISSN. 1996-0786

Mundia, C; Aniya, M (2006). Dynamics of Landuse/Cover Changes and degradation of Nairobi City, Kenya. Land Degrad. Develop. (17): 97-108. DOI: 10.1002/Ldr.702

Mwavu, E; Witkowski, T (2008). Land-use and cover changes (1988-2002) around Budongo forest reserve, NW Uganda: implications for forest and woodland sustainability.

NBS (2003). National Biomass Study Technical Report of 1996-2002. ISBN: 9970863002

Peng, J; Wu, J; Yin, H; Li,Z; Chang, Q; Mu, T (2008). Rural land use change during 1986-2002 in Lijiang, China based in Remote Sensing and GIS data. Sensors Vol. (8) Pp.8201-8223.

Place, F; Otsuka, K (1997). 'Population, land tenure, and natural resource management: the case of customary land area in Malawi', Environment and Production Technology Division Discussion Paper No. 27, International Food Policy Research Institute, Washington, D.C.

Ramankutty, N; Foley, JA; Olejniczak, NJ (2002). People on the land: Changes in global population and croplands during the 20th century. Ambio (31): 251257

SOER (2004). State of Environment Report for Kanungu District.

UBOS (2002). Uganda Population and Housing Census Atlas 